\title{
Viral Hemagglutinin Purification
}

National Cancer Institute

\section{Source}

National Cancer Institute. Viral Hemagglutinin Purification. NCI Thesaurus. Code

C157217.

The process used to isolate hemagg lutinin from a viral sample. 